\title{
ЕФЕКТИВНІСТЬ ЛОКАЛЬНОГО ІНДИВІДУАЛЬНОГО ПРОТОКОЛУ ХІРУРГІЧНОГО ЛІКУВАННЯ ХВОРИХ НА ПРОЛІФЕРАТИВНУ ДІАБЕТИЧНУ PЕТИНОПАТІЮ
}

\author{
А. М. Рубан \\ Національна медична академія післядипломної освіти імені П. Л. Шупика
}

\begin{abstract}
На базі оцінки сумарного ризику, інтегральної оцінки тяжкості стану хворого та визначення ризику хірургічного лікування розроблений локальний індивідуальний протокол хірургічного ведення хворих на діабетичну проліферативну ретинопатію.

Проаналізована ефективність хірургічного лікування хворих на ДПР за запропонованим локальним індивідуальним протоколом з урахуванням групи індивідуального ризику в ретроспективному дослідженні 235 операцій (вітректомій) в неселективній когорті 235 паціентів. Вивчені результати операцій та рівень найбільш вагомих інтраопераційних та післяопераційних ускладнень. В групі хворих, які прооперовані згідно із запропонованим нами індивідуальним протоколом, отримані більш високі анатомічний та функціональний результати операції (вітректомії) та менший рівень інтраопераційних та післяопераційних ускладнень, порівняно зі стандартним протоколом ведення цієї категорії хворих.
\end{abstract}

Ключові слова: проліферативна діабетична ретинопатія, вітректомія 23/25G, протокол лікування, результати вітректомії.

\section{ЭФФЕКТИВНОСТЬ ЛОКАЛЬНОГО ИНДИВИДУАЛЬНОГО ПРОТОКОЛА ВЕДЕНИЯ БОЛЬНЫХ С ПРОЛИФЕРАТИВНОЙ ДИАБЕТИЧЕСКОЙ РЕТИНОПАТИЕЙ}

\begin{abstract}
А. Н. Рубан
Национальная медицинская академия последипломного образования имени П. Л. Шупика

На основании оценки суммарного риска, интегральной оценки тяжести состояния пациента и определения риска проведения операции (витрэктомии) разработан локальный индивидуальный протокол хирургического ведения больных с диабетической пролиферативной ретинопатией.

Проанализирована эффективность хирургического лечения больных с ДПР согласно предложенного локального протокола в ретроспективном исследовании 235 операций (витрэктомий) в неселективной когорте 235 пациентов. Изучены результаты операции и уровень наиболее значимых интраоперационных и послеоперационных осложнений. В группе пациентов, прооперированных по предложенному нами протоколу, получены более высокие анатомический и функциональный результаты операции и меньший уровень интраоперационных и послеоперационных осложнений, в сравнении с группой со стандартным протоколом ведения данной категории больных.
\end{abstract}

Ключевые слова: пролиферативная диабетическая ретинопатия, витрэктомия 23/25G, протокол лечения, результаты витрэктомии.

\section{EFFICIENCY OF THE LOCAL INDIVIDUAL PROTOCOL OF SURGICAL TREATMENT (VITRECTOMY) PATIENTS WITH DIABETIC PROLIFERATIVE RETINOPATHY}

\begin{abstract}
A. M. Ruban
National Medical Academy of Postgraduate Education by P. L. Shupyk

The article propose a new system support of making decision during vitrectomy in patients with diabetic proliferative retinopathy, according by objective assessment of individual risk-management. The article presents some comparative results (anatomical and functional results, rate of complications) between two groups: with new and standard approaches.
\end{abstract}

Key words: diabetic proliferative retinopathy, vitrectomy $23 / 25 \mathrm{G}$.

\footnotetext{
(C) А. М. Рубан
} 
Вступ. Діабетичне ураження сітківки залишається головною причиною важкої втрати зору у пацієнтів працездатного віку в усіх розвинутих країнах світу [1]. Сліпота у хворих на цукровий діабет зустрічається у 25 разів частіше, ніж у осіб, які не страждають на це захворювання [2]. В більшості випадків причиною втрати зору є проліферативна діабетична ретинопатія (ПДР), що призводить до рецидивуючого вітреального крововиливу та тракційного відшарування сітківки [3].

Фінансові витрати, пов'язані зі сліпотою, яка викликана діабетичною проліферативною ретинопатією, лягають тягарем на національну систему охорони здоров'я та систему соціального страхування. Приміром, на початку 90-х років минулого століття річні соціальні виплати сліпим внаслідок діабетичної ретинопатії в США наближались до 500 млн доларів [4]. Але реальні сучасні витрати є значно більшими, оскільки вкрай складно вирахувати побічні втрати внаслідок неможливості брати участь у виробництві великої кількості осіб працездатного віку з низьким зором внаслідок діабетичної ретинопатії. Ніякий економічний аналіз не спроможний також врахувати «вартість» інвалідності по зору з точки зору якості життя та соціальної адаптації. Хворим на цукровий діабет тяжче знайти високооплачувану роботу, крім того, значна частина працюючих пацієнтів з ДР мають великий ризик залишитися без роботи впродовж 4 років [5].

У багатоцентрових рандомізованих дослідженнях були отримані докладні дані щодо епідеміології діабетичних уражень сітківки та їх прогресування, визначені фактори ризику розвитку ДР та ефективність лазерного лікування і вітреоретинальної хірургії [6]. Отримані результати лягли в основу сучасних стандартів допомоги хворим з діабетичною ретинопатією [7].

Існуючі схеми динамічного спостереження та вибору тактики хірургічного лікування хворих на ДПР дуже розпливчасті та не враховують індивідуальні особливості пацієнта і варіанти перебігу патологічного процесу.

Все вищезгадане свідчить про те, що існуючі на сьогодні рекомендації не можна вважати оптимальним протоколом хірургічного ведення хворих на ПДР, оскільки вони характеризують лите загальні лікувально-діагностичні підходи та не враховують індивідуальних особливостей і поліморфності проявів патологічного процесу.

Мета роботи - розробити та визначити ефективність запропонованого індивідуального протоко- лу хірургічного ведення хворих на ДПР з урахуванням групи індивідуального ризику.

Матеріали та методи. Для вирішення завдання індивідуального прогнозування ризику хірургічного лікування хворих на ПДР ми застосовували методики, пов'язані з бальними критеріями, при яких одне 3 провідних місць займає визначення прогностичної значимості клінічних ознак. На підставі дослідження та аналізу 145 клінічних ознак, які характеризують загальний стан і офтальмологічний статус пацієнта, нами були визначені і опубліковані найбільш значимі показники, які й були об'єднані в карту ризику [8].

На основі аналізу отриманої графічної залежності вірогідності незадовільного результату операції від суми балів ми виділили 4 ступені ризику оперативного втручання - низький ризик (перший ступінь ризику, <5 балів), відповідна ймовірність несприятливого результату менше 5 \% і відображає нижню, майже горизонтальну частину кривої, середній ризик (другий ступінь ризику, 5-15 балів), з ймовірністю несприятливого результату $5-40 \%$; високий ризик (третій ступінь ризику, 16-25 балів), ймовірність несприятливого результату - 41-90\% i надмірний ризик (четвертий ступінь ризику, $>25$ балів), $з$ ймовірністю незадовільного результату більше $90 \%$ [9].

Отримані дані стали основою запропонованого нами протоколу хірургічного лікування хворих на ПДР (рис. 1).

Зметою порівняння ефективності хірургічного лікування (вітректоміi) хворих на ПДР за стандартним та запропонованим протоколами нами було проведено ретроспективне дослідження 255 операцій (вітректомій) в неселективній когорті 255 пацієнтів із ПДР (255 очей) в період з березня 2010 по жовтень 2013 року в Київський клінічній офтальмологічній лікарні «Центр мікрохірургії ока). Вивчали результати операцій та рівень найбільш вагомих інтраопераційних та післяопераційних ускладнень. Першу групу: IC (стандартний протокол) склали 123 хворих, другу групу: П (запропонований протокол) склали 112 хворих на ПДР. У кожній групі було виділено 4 підгрупи (залежно від ступеня ризику операціi): 1) низький ризик; 2) середній ризик; 3) високий ризик; 4) надмірний ризик.

Анатомічний успіх визначали як повне прилягання сітківки, або при стабільній ситуації з локальним периферійним відшаруванням сітківки, розташованим попереду екватора розміром менше ніж один квадрант. Наявність локального тракційного відшарування сітківки >1 квадранта, або регматогенного 


\begin{tabular}{|c|c|}
\hline Хворий на ПДР & $\begin{array}{c}\text { Інтегральна оцінка тяжкості } \\
\text { стану хворого }\end{array}$ \\
\hline & операції \\
\hline & 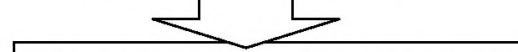 \\
\hline $\begin{array}{l}\text { СТАНДАРТНИЙ ПРОТОКОЛ } \\
\text { ХІРУРГІЧНОГО ЛІКУВАННЯ }\end{array}$ & $\begin{array}{c}\text { ПРОТОКОЛ ХІРУРГІЧНОГО } \\
\text { ЛІКУВАННЯ } 3 \\
\text { УРАХУВАННЯМ РИЗИКУ }\end{array}$ \\
\hline Універсальні: & Індивідуальні: \\
\hline $\begin{array}{l}\text { • строки проведення } \\
\text { операції; } \\
\text { • підготовка до операції; } \\
\text { • обсяг і вид оперативного } \\
\text { втручання; } \\
\text { • післяопераційний } \\
\text { моніторинг. }\end{array}$ & $\begin{array}{l}\text { • строки проведення } \\
\text { операції; } \\
\text { • підготовка до операції; } \\
\text { • обсяг і вид оперативного } \\
\text { втручання; } \\
\text { • післяопераційний } \\
\text { моніторинг. }\end{array}$ \\
\hline
\end{tabular}

Puc. I. Схема ведення хворих на ПДДР за стандартним та запропонованим протоколами хірургічного лікування.

відшарування сітківки розцінювалось нами як незадовільний анатомічний результат. Незадовільний функціональний результат визначався при максимально коригованій гостроті зору <0,1 [10].

Показаннями для проведення вітректомії в обох групах були: вітреоретинальний крововилив трива- лістю більше 1 міс., тракційне або тракційно-регматогенне відшарування сітківки. До груп не ввійшли пацієнти з первинним регматогенним відшаруванням сітківки, увеїтом або травмою. Мінімальний термін спостереження склав 6 місяців. Детальні характеристики пацієнтів наведені в таблицях 1,2 .

Таблиця 1. Якісні характеристики пацієнтів до операції

\begin{tabular}{|l|c|c|c|c|}
\hline \multirow{2}{*}{\multicolumn{2}{|c|}{ Показники }} & \multicolumn{2}{c|}{ I група } & \multicolumn{2}{c|}{ II група } \\
& 123 паціснти (123 ока) & 112 паціснтів (112 очей) \\
\cline { 2 - 5 } & абс. & $\%$ & aбс. & \% \\
\hline Кількість чоловіків & 72 & 58,5 & 61 & 54,4 \\
\hline Кількість жінок & 51 & 41,5 & 51 & 45,6 \\
\hline Кількість пацієнтів 3 ЦД 1 типу & 53 & 43 & 49 & 43,7 \\
\hline Кількість пацієнтів 3 ЦД 2 типу, які приймають інсулін & 40 & 32,5 & 29 & 25,8 \\
\hline Кількість пацієнтів 3 ЦД 2 типу, які не приймають інсулін & 30 & 24,3 & 34 & 30,5 \\
\hline
\end{tabular}

Як видно з таблиці 1 , жодна якісна характеристика складу пацієнтів в першій та другій групах статистично не відрізняються $(p>0,05)$.

Аналогічну ситуацію отримали при зівставленні кількісних характеристик в цих же групах.

Таб̆лиця 2.Кількісні характеристики пацієнтів до операції

\begin{tabular}{|l|c|c|c|c|}
\hline \multirow{2}{*}{\multicolumn{1}{|c|}{ Показники }} & \multicolumn{2}{c|}{$\begin{array}{c}\text { I група } \\
123 \text { паціснти } \\
\text { (123 ока) }\end{array}$} & \multicolumn{2}{c|}{$\begin{array}{c}\text { II група } \\
\text { (12 паціснтів } \\
\text { (112 очей) }\end{array}$} \\
\cline { 2 - 5 } & aбc. & $\pm \mathrm{m}$ & абс. & $\pm \mathrm{m}$ \\
\hline Середній вік пацієнтів у групі, років & 49 & 1,1 & 52 & 1,5 \\
\hline Середній вік пацієнтів 3 ЦД 1 типу років & 35 & 0,7 & 32 & 0,8 \\
\hline Середній вік пацієнтів 3 ЦU 2 типу, які приймають інсулін, років & 54 & 0,8 & 57 & 0,6 \\
\hline Середній вік пацієнтів 3 ЦД 2 типу, які не приймають інсулін, років & 64 & 0,7 & 66 & 0,9 \\
\hline Середній вік пацієнтів на час операції, років & 48 & 1,1 & 52 & 1,4 \\
\hline
\end{tabular}


Базове обстеження органа зору, яке проводили усім пацієнтам, визначали як стандартне офтальмологічне обстеження. До нього входили:

- Візометрія (без корекції, з корекцією);

- Біомікроскопія переднього відрізка ока за допомогою щілинної лампи;

- Вимірювання внутрішньоочного тиску;

- Біомікроскопія кришталика та склоподібного тіла;

- Біомікроскопія сітківки за допомогою асферичних лінз високої діоптрійності або контактних лінз (на широкійзіниці);

- Періметрія (динамічна або статична).

При необхідності додатково проводили: УЗ-сканування заднього відрізка ока, оптичну когерентну томографію(ОСТ), флуоресцентну ангіографію сітківки (ФАГ).

За стандартною методикою малоінвазивної вітректомії операції виконувались на субтеноновій анестезії за класичною методою 3-х портів 3 використанням інструментів калібру $23 / 25 \mathrm{G}$ («one step») на хірургічному комплексі «Stellaris PC» (Bausch\&Lomb). Oneрація починалась 3 виконання факоемульсифікації кришталика через рогівковий розтин 1,8-2,0 мм на 11 годинах та імплантації акрилової IOЛ(Bausch\&Lomb). Далі, транскон'юнктивально і транссклерально, на відстані 3,5 мм від лімбу за методикою J. Pollack (вхід троакара під кутом 5-10 ${ }^{\circ}$ до поверхні склери) імплантували три канюлі, через які високошвидкісним вітреотомом (5000 зр/хв) видаляли центральне склоподібне тіло та проводили усунення передньо-задніх тракцій заднього кортикального гелю (ЗКГ). Максимально повне видалення фіброваскулярних мембран виконували технікою деламінації, сегментації або їх комбінації. При виконанні бімануальної техніки використовували додаткове освітлення 25G (Awh, Stellaris), 29G (chandelier, Synergetics) (рис. 2). За можливості проводили панретинальну лазерну коагуляцію максимально периферійно (до ora serrata). Для візуалізації очного дна використовували ширококутову систему Resight (Carl Zeiss Meditec, Germany). При виконанні маніпуляцій на макулярній ділянці ми використовували контактну лінзу (Dorc, Netherlands). Силіконову або газову тампонаду проводили за визначенням хірурга. В тих випадках, коли тампонада не планувалась, в кінці операції проводилась часткова $(<30 \%)$ тампонада стерильним повітрям 3 метою профілактики післяопераційної гіпотонії [11].

Результати та їх обговорення. Основою нового протоколу хірургічного ведення пацієнтів з ПДР мають стати клінічні моделі хворих та лікувально-діагностичний алгоритм. Клінічна модель паціснта являс собою спрощений схематичний опис сукупності

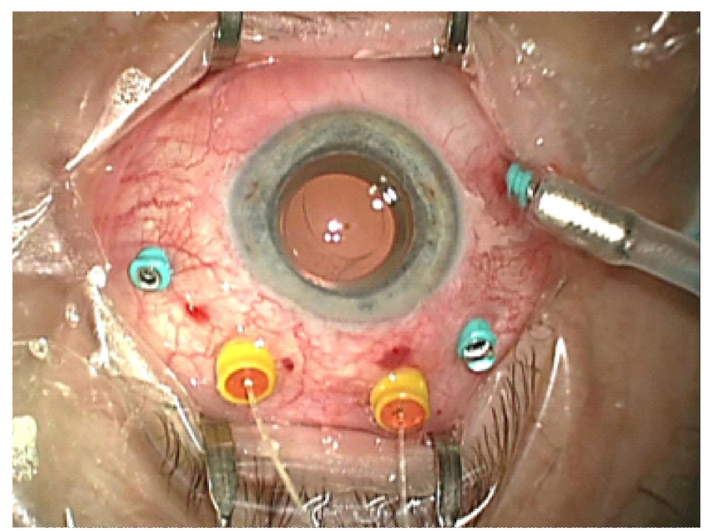

Puc. 2. Малоінвазивна вітректомія при ПДР.

клінічних проявів, варіантів перебігу захворювання та його ускладнень, який регламентує необхідний перелік обов'язкових лікувально-діагностичних заходів та умов для їх виконання (лікувально-діагностичний алгоритм).

Впровадження системи прогнозування ризиків незадовільного результату та виникнення ускладнень хірургічного лікування хворих на цукровий діабет сприяс об’ сктивізації індивідуальної оцінки ризиків для кожного пацієнта, що дозволяє значно покращити якість надання офтальмологічної допомоги хворим на цукровий діабет.

Проблеми зі створенням сучасних протоколів хірургічного ведення хворих на проліферативну діабетичну ретинопатію багато в чому пов'язані з відсутністю індивідуального підходу до хворого. Оцінка сумарного ризику (на базі інтегральної оцінки тяжкості стану хворого) $є$ необхідним компонентом при розробці рекомендацій в профілактичній офтальмології, особливо в індивідуальній профілактиці, або, як визначають експерти ВООЗ, у стратегії високого ри-

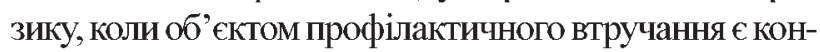
кретний пацієнт або невелика група (когорта) пацієнтів, які мають схожі характеристики за основними факторами, які впливають на прогноз операції.

Очевидно, що аналіз інформації про пацієнта при плануванні вітректомії повинен проводитися послідовно, в заздалегідь встановлені терміни. На кожному наступному етапі необхідно зробити прогноз подальшого стану та очікуваного результату. Такий клінічний моніторинг як система спостереження, аналізу, оцінки і прогнозу стану хворих є з одного боку засобом управління ризиками, а 3 іншого-системою підтримки прийняття рішень, що обумовлює оперативне та ефективне вирішення питань тактики проведення вітректомії при ПДР і надає пацієнтові відомості про його реальний ризик.

Запропонований нами протокол хірургічного ведення хворих на ПДР наведений в таблиці 3. 
Таблиця 3. Протокол хірургічного ведення хворих на ПДР

\begin{tabular}{|c|c|}
\hline $\begin{array}{l}\text { Клінічні моделі хворих } \\
\text { на ДПР (групи ризику) }\end{array}$ & Лікувально-діагностичний алгоритм \\
\hline $\begin{array}{l}\text { Низький ризик: } \\
\text { - сума балів (<5 балів) } \\
\text { - ризик незадовільного } \\
\text { результату операції } \\
<5 \%\end{array}$ & 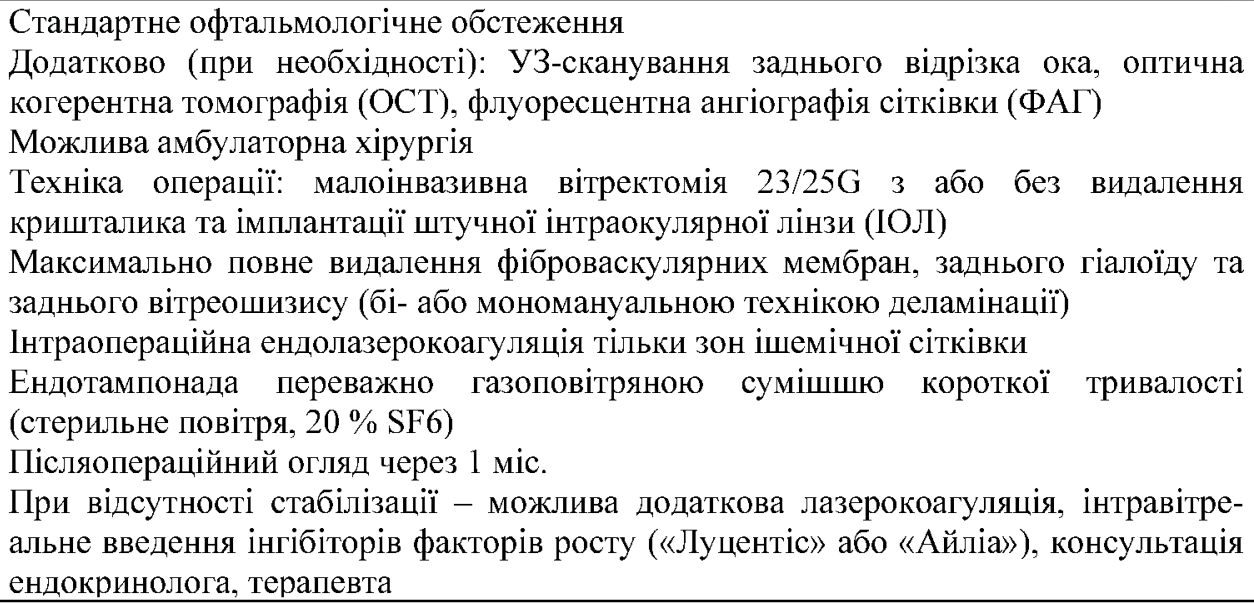 \\
\hline $\begin{array}{l}\text { Середній ризик: } \\
\text { - сума балів (5-15 балів) } \\
\text { - ризик незадовільного } \\
\text { результату операції } \\
5-40 \%\end{array}$ & 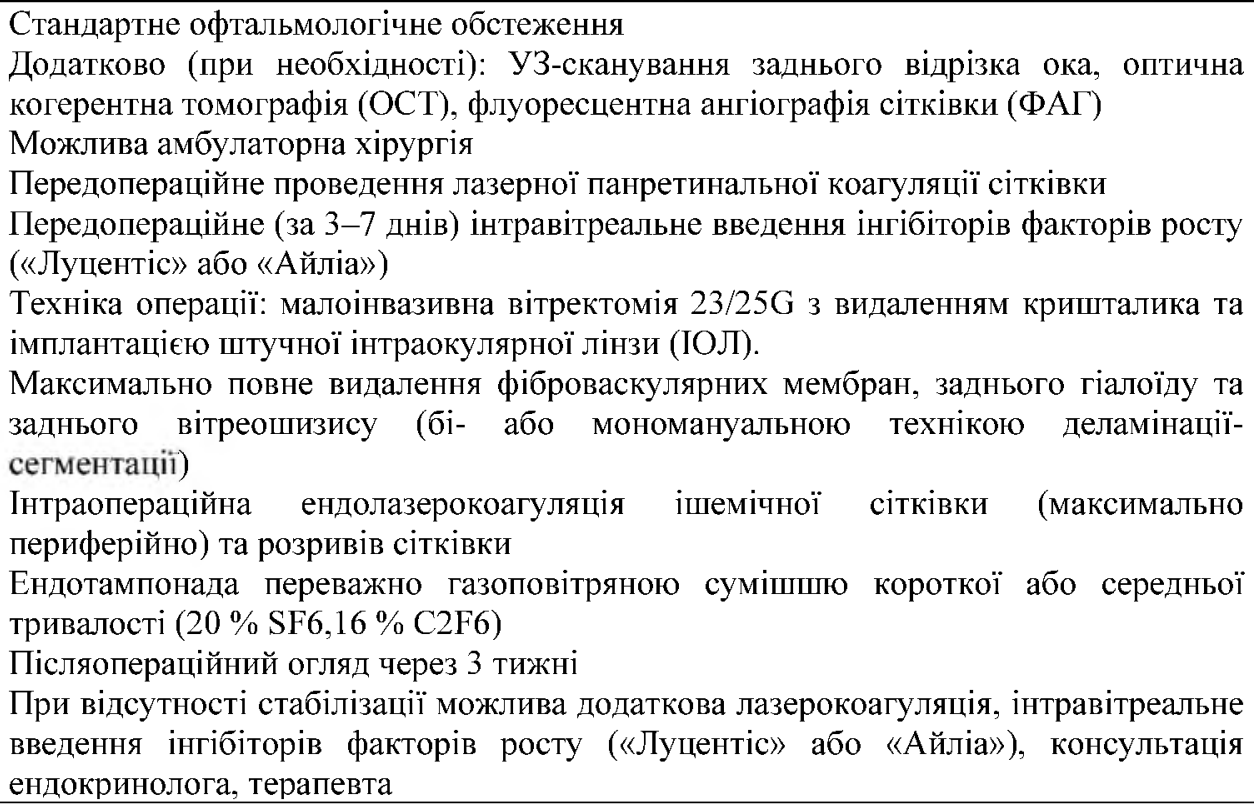 \\
\hline $\begin{array}{l}\text { Високий ризик: } \\
\text { - сума балів (16-25) } \\
\text { - ризик незадовільного } \\
\text { результату операції } \\
41-90 \%\end{array}$ & $\begin{array}{l}\text { Стандартне офтальмологічне обстеження } \\
\text { Додатково (при необхідності): У3-сканування заднього відрізка ока, оптична } \\
\text { когерентна томографія (ОСТ), флуоресцентна ангіографія сітківки (ФАГ) } \\
\text { Операція виконується в стаціонарі (1-3 дні) } \\
\text { Консультація ендокринолога, терапевта, анестезіолога } \\
\text { Передопераційне (за 3-7 днів) інтравітреальне введення інгібіторів факторів росту } \\
\text { Техніка операції: малоінвазивна бімануальна вітректомія 23/25G } 3 \text { видаленням } \\
\text { кришталика та імплантацією штучної інтраокулярної лінзи (IOЛ) та максимально } \\
\text { повним видаленням фіброваскулярних мембран, заднього гіалоїду та заднього } \\
\text { вітреошизису. } \\
\text { Максимально повне проведення інтраопераційної ендолазерокоагуляції ішемічної } \\
\text { сітківки, розривів сітківки } \\
\text { Ендотампонада переважно газоповітряною сумішшю середньої тривалості (16\% } \\
\text { С2F6), або силіконовою олією (1300/5700 сSt) } \\
\text { Інтравітреальне введення кортикостероїдів } \\
\text { Післяопераційний огляд через } 2 \text { тижні } \\
\text { При відсутності стабілізації - можлива додаткова лазерокоагуляція, інтравітре- } \\
\text { альне введення інгібіторів факторів росту («Луцентіс» або «Айліа»), консультація } \\
\text { ендокринолога, терапевта }\end{array}$ \\
\hline
\end{tabular}




\begin{tabular}{|c|c|}
\hline $\begin{array}{l}\text { Надмірний ризик: } \\
\text { - сума балів (> 25) } \\
\text { - ризик незадовільного } \\
\text { результату операції >90\% }\end{array}$ & $\begin{array}{l}\text { Стандартне офтальмологічне обстеження } \\
\text { Додатково (при необхідності): УЗ-сканування заднього відрізка ока, оптична } \\
\text { когерентна томографія (ОСТ), флуоресцентна ангіографія сітківки (ФАГ) } \\
\text { Консультація ендокринолога, терапевта, анестезіолога } \\
\text { Операція проводиться при монокулярному зорі (єдине зряче око) в стаціонарі } \\
\text { (1-3 дні) } \\
\text { Передопераційне проведення лазерної панретинальної коагуляції сітківки } \\
\text { Передопераційне (за } 3-7 \text { днів) інтравітреальне введення інгібіторів факторів } \\
\text { росту («Луценті» або «Айліа») } \\
\text { Техніка операції: малоінвазивна бімануальна вітректомія 23/25G, видалення } \\
\text { кришталика та імплантація штучної інтраокулярної лінзи (ІОЛ) та часткове } \\
\text { видалення фіброваскулярних мембран (техніка сегментації) в макулярній } \\
\text { ділянці. } \\
\text { Максимально повне проведення інтраопераційної ендолазерокоагуляції } \\
\text { ішемічної сітківки, розривів сітківки } \\
\text { Ендотампонада силіконовою олією (5700 сSt) } \\
\text { Інтравітреальне введення кортикостероїдів } \\
\text { Післяопераційний огляд через } 1 \text { тиж. } \\
\text { При відсутності стабілізації можлива додаткова лазерокоагуляція, } \\
\text { інтравітреальне введення інгібіторів факторів росту («Луцентіс» або «Айліа»), } \\
\text { консультація ендокринолога, терапевта }\end{array}$ \\
\hline
\end{tabular}

Результати хірургічного лікування хворих на ПДР з різними групами ризику за стандартним та запропонованим протоколом наведені в таблиці 4.
Отримані нами дані свідчать про те, що кращі анатомічні та функціональні результати досягнуті в II групі (індивідуальний протокол), порівняно з І групою

Таб̆лиця 4. Порівняльний аналіз результатів хірургічного лікування хворих на ПДР з різними групами ризику операційного втручання за стандартним та запропонованим протоколами

\begin{tabular}{|c|c|c|c|c|c|c|c|c|}
\hline & \multicolumn{7}{|c|}{ Групи пацієнтів за ризиками. 3начення показників, \% } \\
\cline { 2 - 10 } & $1 \mathrm{C}$ & 1 & $2 \mathrm{C}$ & 2 & $3 \mathrm{C}$ & 3 & $4 \mathrm{C}$ & 4 \\
\hline Кількість пацієнтів & 25 & 28 & 38 & 33 & 43 & 37 & 17 & 14 \\
\hline АР & 92 & 96 & 88 & 94 & 85 & 92 & 72 & 81 \\
\hline ФР & 45 & 65 & 30 & 54 & 21 & 42 & 12 & 21 \\
\hline Інтраопераційні ускладнення: & & & & & & & & \\
ЯРС & 15 & 8 & 25 & 12 & 35 & 16 & 55 & 20 \\
Кр & 35 & 17 & 45 & 22 & 60 & 35 & 90 & 55 \\
\hline Післяопераційні ускладнення: & & & & & & & & \\
НГ & 5 & 3 & 7,5 & 3,5 & 8 & 5 & 11,5 & 7 \\
Кр & 30 & 22 & 47 & 31 & 60 & 35 & 85 & 48 \\
\hline
\end{tabular}

* - різниця між групами стандартного протоколу лікування та персоніфікованого лікування статистично значима (р<0,05). 1C-4C - підгрупи стандартного протоколу лікування; 1-4-підгрупи персоніфікованого лікування; АР - анатомічний результат; ФР - функціональний результат; ЯРС - ятрогенші розриви сітківки; ВС - відшарування сітківці; Кр - крововилив; НВ неоваскулярна глаукома.

(стандартний протокол). Валідність отриманих результатів підтверджена для всіх підгруп. Рівень таких важких інтраопераційних ускладнень, як ятрогенні розриви сітківки та преретинальні крововиливи, також виявився значно нижчим у ІІ групі. Частота післяопераційних ускладнень в нашому дослідженні (таких як: неоваскулярна глаукома, рецидивуючий крововилив та відшарування сітківки) також була меншою в П групі.
Слід зазначити, що більш високі анатомічний та функціональний результати вітректомії та менший рівень інтраопераційних іпісляопераційних ускладнень в II групі може бути пов'язаний з позитивним впливом декількох факторів: 1) краца передопераційна підготовка хворих, а саме: обов'язкове передопераційне введення інгібітора ендотеліального фактора росту (VEGF), проведення максимально повної панретинальноїлазерокоагуляції, консультації ендокрино- 
лога; 2) використання запропонованої нами бімануальної техніки дисекції фіброваскулярних мембран при задньому вітреошизисі; 3) обов' язкове проведення максимально повної інтраопераційної панретинальної лазерокоагуляції; 4) оптимізація проведення силіконових ендотампонад та оптимізація термінів післяопераційного моніторінгу $[12,13,14]$.

Підкреслимо, що недостатня кількість клінічних випадків для ступенів ризику в матеріалах дослідження не дозволила нам отримати статистичне підтвердження в усіх випадках. Водночас тенденція до покращання результатів хірургічного лікування діабетичної ретинопатії при використанні локального протоколу (що пропонується) очевидна. Це дає всі підстави для продовження розпочатих досліджень.

\section{Лiтература}

1. Global prevalence of diabetes: estimates for the year 2000 and projections for 2030 / S. Wild, G. Roglic,A. Green [et al.]// Diabetes Care.-2004. - Vol. 27.-P. 1047-1053.

2. Klein R. The epidemiology of ocular problems in diabetes mellitus / R. Klein, B. E. K. Klein, S. E. Moss. In: S. S. Feman ed. Ocular Problems in Diabetes Mellitus. - St. Louis : CV Mosby Co, 1989.-P. 255-264.

3. Prevalence and risk factors for diabetic retinopathy. The Singapore Malay eye study / T. Y. Wong, N. Cheung, W. T. Tay, [et al.] //Ophthalmology. -2008. - Vol. 115.-P. 1869-1875.

4. Jochmann C. Epidemiology, pathogenesis and therapy of diabetic retinopathy and maculopathy / C. Jochmann, H. P. Hammes // Z.Arztl. Fortbild Qualitatssich.-2002.-Vol. 96. P. 167-174.

5. Mohamed Q. Management of diabetic retinopathy: a systematic review/Q. Mohamed, M. C. Gillies, T. Y. Wong // J.A.M.A. - 2007. - Vol. 298.-P. 902-916.

6. Smiddy W. E. Jr. Vitrectomy in the management of diabetic retinopathy /W. E. Smiddy, H. W. Flynn// Surv. Ophthalmol.1999 - Vol. 43. - P. 491-507.

7.Шадричев Ф. Е. Протокол офтальмологического ведения больных с сахарным диабетом / Ф. Е. Шадричев // Офтальмологические ведомости.-2008. - Т. 1, № 2.-С. 5461.

8. Рубан А. М. Фактори ризику в прогнозуванні виходу хірургічного лікування проліферативної діабетичної ретинопатії / А. М. Рубан, С. О. Риков, А. Ю. Зольнікова // Медична інформатика та інженерія. - 2012. - № 1.- С. 11-15.
Висновки. 1. Використання запропонованого протоколу на практиці дозволяє детально враховувати індивідуальні особливості різноманітних клінічних проявів патологічного процесу, пов'язаного з ДПР. Це має привести до своєчасного та адекватного реагування зі сторони лікаря на прогресування змін, i, як наслідок, до підвищення ефективності хірургічного лікування даної категорії хворих.

2. Запровадження запропонованого протоколу хірургічного лікування (вітректоміiі) в систему надання спеціалізованої офтальмологічної допомоги хворим на проліферативну діабетичну ретинопатію може значно зменшити кількість нових випадків сліпоти внаслідок діабетичного ураження сітківки, порівняно з традиційними підходами.

9. Рубан А. М. Система підтримки прийняття рішень при проведенні вітректомії у хворих на діабетичну проліферативну ретинопатію / А. М. Рубан // Медична інформатика та інженерія. -2014. - № 1. - С. 15-20.

10. Рубан А. М. Інформаційне забезпечення стратегії визначення оптимальної тактики хірургічного лікування хворих з проліферативною діабетичною ретинопатією // Медична інформатика та інженерія. - № 3. - С. 56-62.

11. Рубан А. М. Результати комбінованої $23 \mathrm{G}$ вітректомії 3 факоемульсифікацією та імплантацією ІОЛ у пацієнтів на проліферативну діабетичну ретинопатію // Офтальмологический журнал. - 2013. - № 2. - С. 3642.

12. Межфазные взаимодействия полидиметилсилоксанов с бнополимерами витреоретинального интерфейса / Рубан А. М., Казанец А. И., Рыков С. А. [и др.] // Офтальмологический журнал. - 2013. - № 3. - С. 46-51.

13. Рубан А. М. Бімануальна мініінвазивна техніка вндалення заднього вітреошизису у пацієнтів на проліферативну діабетичну ретинопатію / А. М. Рубан: 3б. наук. праць співробіт. НМАПО імені П. Л. Шупика. -2013. - №22(4). С. $90-97$.

14. Родин С. С. Бевацизумаб (авастин) в комплексном хирургическом лечении больных с пролиферативной стадией диабетической ретинопатии / С. С. Родин, В. С. Асланова // Український медичний альманах. - 2008. - Т. 11, №3.C. $126-128$. 